\title{
The impact on the environmental protection of the Regional Operational Programme for the environment and infrastructure for the Lower Silesia Voivodeship for 2007-2013
}

\author{
Author: Bartosz Bartniczak
}

\begin{abstract}
:
The state of the environment and environmental infrastructure is one of the factors determining the quality of life of residents in a given territory. The main objective of the Regional Operational Programme for the Lower Silesia voivodeship for 2007-2013 (ROP) was to increase the standard of livingin Lower Silesia, and to improve the competitiveness of the region while respecting the principles of sustainable development. Implementation of this objective was to be achieved through the implementation of the specific objectives assigned to individual priorities. The aim of the priority IV Environment and Ecological Safety was the improvement of the environment, the prevention of its degradation, the conservation of the biodiversity and natural assets of Lower Silesia, as well as the improvement of safety in the region through counteracting natural and technological risks and through eliminating their effects and supporting the activity of emergency services.
\end{abstract}

Objective

The objective of this study is to show how the implementation of projects funded under Priority IV contributed to the improvement of the state of the environment and the infrastructure for environmental protection.

Survey method

In the paper the desk research method were used. The results of completed projects will be compared to statistic data concerning the state of the environment and environmental infrastructure in the region. I will analyse the environmental components that correspond to the topics of the various activities carried out under Priority IV. The analysis will therefore be conducted in the area of waste, water and wastewater management, air quality, flood protection infrastructure, restoration of degraded land, protection of the environment from natural and technological risks and conservation of the biodiversity. 


\section{Conclusions}

The carried out analysis shows that analysed projects contributed greatly to improve waste management in the voivodeship and to improve water and sewerage infrastructure. The analysed projects had little impact on improving air quality in the voivodeship, improvement in flood protection infrastructure.

Originality

The article presents the results of the author's research. The results helped to identify the impact of the investments on the environment in the voivodship.

Keywords: Regional Operational Programme, environment, Lower Silesia Voivodeship

JEL: H25

\section{Introduction}

The term enviroment is uderstood very widely. Because of that the components of this term are person, fauna, flora, soil, water, air, climate, landscape, as well as material resources, cultural heritage, natural environment and natural resources, and water resources. The concept of the environment also includes elements of the social environment of man, social conditions of life of the individual and socjety [Kenig-Witkowska: 2011, s. 19]. Therefore, an important issue is to identify the resources from European funds contribute to improving the environment but also environmental protection infrastructure. Such analysis may in fact show that the provision of support contributes to the achievement of specific objectives set in the individual operational programs, and consequently has an impact on the environment in a given area. In this paper an attempt is made to determine the impact on the basis of the ROP for the Lower Silesian voivodeship.

The main objective of Regional Operational Programme for the Lower Silesian voivodeship for 2007-2013 was: to improve the quality of life of Lower Silesia inhabitants and to increase
History: otrzymano 2015-10-23, poprawiono 2016-04-07, zaakceptowano 2016-04-27

the region's competitiveness while respecting principles of sustainable development [Lower Silesia Marshal's Office 2008]. The Programme had also three detailed objectives:

1. To increase the economic activity based on knowledge and innovation.

2. To develop an infrastructure that facilitates the improvement in the quality of the environment, investment conditions and running business activity.

3. To improve the living conditions of the inhabitants and the growth of competitiveness of the region through modernisation and development of the social infrastructure.

From the environmental point of view the second objective was the most important. ROP support was granted under 10 thematic priorities. One of them, Priority four: Improvement of the Natural Environment and Improvement of Ecological and Flood Safety in Lower Silesia was connected to the environmental protection.

This priority was divided into seven actions. The implementation of each of them should have contributed to the achievement of specific objectives (tab.1). 
Table 1. Objectives of each action under Priority IV

\begin{tabular}{|c|c|}
\hline Action & Objective \\
\hline 4.1 Waste management & $\begin{array}{l}\text { To improve the environment and prevent its degradation } \\
\text { by re-organizing the waste management operation. }\end{array}$ \\
\hline $\begin{array}{l}\text { 4.2 Water and sewage } \\
\text { infrastructure }\end{array}$ & $\begin{array}{l}\text { To improve the environment and living } \\
\text { conditions by organizing water and wastewater } \\
\text { infrastructure and expanding water supply. }\end{array}$ \\
\hline $4.3 \mathrm{Improvement}$ of air quality & To improve air quality by reducing emissions from utilities. \\
\hline 4.4 Flood and drought prevention & $\begin{array}{l}\text { To reduce the risk of flood, to prevent drought and } \\
\text { to combat its effects by supporting the construction } \\
\text { and modernizing the necessary infrastructure. }\end{array}$ \\
\hline 4.5 Reclamation of degraded areas & $\begin{array}{l}\text { To improve the quality of the environment through } \\
\text { the rehabilitation of degraded areas (mainly post- } \\
\text { industrial and post-military), which consists in converting } \\
\text { them into nature conservation and recreational } \\
\text { areas or using them in the green economy. }\end{array}$ \\
\hline $\begin{array}{l}\text { 4.6 Support for institutions dealing } \\
\text { with environmental protection }\end{array}$ & $\begin{array}{l}\text { To increase protection against the effects of natural and } \\
\text { technological hazards, to remove their effects, to restore the } \\
\text { environment's conditions and to strengthen the selected } \\
\text { elements of the environmental management system. }\end{array}$ \\
\hline $\begin{array}{l}4.7 \text { Biodiversity conservation } \\
\text { and environmental education }\end{array}$ & To preserve the environmental potential of the region. \\
\hline
\end{tabular}

Source: [Lower Silesia Marshal's Office 2008].

A very important question to answer will therefore be: how the projects implemented under the ROP contributed to the regeneration of the environment, as well as to the improvement of the environmental infrastructure in the voivodeship. The analysis will allows us to identify the areas where the impact was very important, but also those in which the effects were insignificant, and thus further support should be provided in the next financial period. The restoration of the environment and the improvement of the infrastructure for environmental protection are achieved thanks to many different sources of investment. Some of them are national (investors' own funds, earmarked funds) but others are foreign [Bartniczak, Ptak 2009: 61-145].

The funds from the European Union have become the main external source of financing the environmental infrastructure in recent years. Many Local Governments decide to invest once financial support has been granted The amount of financial sources, however, are severely restricted. Therefore, it is very important to identify the areas in which thanks to the granted support we will notice a significant improvement, and those in which such support should continue to be granted.

It should also be noted that providing support in environmental protection can be achieved a number of additional effects. Reduce environmental pollution, improve air and water quality can affect the decrease in morbidity, mortality reduction of society, reducing expenditures, for example on repairs to buildings, but also on the growth of tourism [Mazur-Wierzbicka: 2008]. The identification the impact of funding from the Structural Funds on the environment is important both from a practical point of view, but also has a scientific aspect. Implementating of any operating program the entity responsible for managing it is obliged 
to carry out analyzes of both ex-ante and ex-post of his influence on a specific sphere. Thanks to this analysis, it will be possible to assess from the point of view of the five evaluation criteria, ie. relevance, efficiency, effectivenes, impacts and sustainability [Beck:2006]. Conducting such an evaluation therefore has direct benefits for the managers program, but also benefits information for the direct recipients of the program. The scientific aspect can be considered from the point of impact of a program to improve the environment. This allows for an indication of the relationship between the size and the scope of investments and achieved improvement of the environment.

The funds from the European Union are granted under several programs implemented at both the national and regional level. The line of demarcation indicates which projects are implemented under the various programs and at what level [Ministry of Infrastructure and Development 2015]. The result is that in some areas the support may be granted only at the national level which means that the intervention at the regional level is very limited.

In years 2007-2013, 221 projects have been granted support under priority IV RPO (tab.2.)._Within those projects nearly $24 \%$ were connected to water and sewage infrastructure and more than $22 \%$ were linked to biodiversity conservation and environmental education. The total value of supported projects was more than 822 mln PLN. The funding from European Union was more than $523 \mathrm{mln}$ PLN. The share of the support of the European Union amounted to more than $63 \%$. Nearly $49 \%$ of support was granted to projects involving water and sewage infrastructure and nearly $20 \%$ in areas of waste management.

The purpose of this article is to show the changes in the environment, as well as changes in the environmental infrastructure in Lower Silesia in 20072013. The next step will be to analyze the effects of the projects co-financed by the ROP. This will allow us to identify areas where intervention of ROP had the greatest impact on the environment restoration and environmental infrastructure.

Table 2. Basic information about supported projects under priority 4

\begin{tabular}{|c|c|c|c|}
\hline Action & $\begin{array}{c}\text { Number of } \\
\text { projects }\end{array}$ & $\begin{array}{c}\text { The total cost of } \\
\text { the projects (PLN) }\end{array}$ & $\begin{array}{c}\text { The amount of } \\
\text { funding with the } \\
\text { European Union (PLN) }\end{array}$ \\
\hline 4.1 Waste management & 35 & 179106055,56 & 102114525,22 \\
\hline $\begin{array}{c}\text { 4.2 Water and sewage } \\
\text { infrastructure }\end{array}$ & 53 & 404033444,72 & 255675015,72 \\
\hline 4.3 Improving air quality & 12 & 5966832,96 & 4551428,91 \\
\hline 4.4 Flood and drought prevention & 18 & 87415316,99 & 61537625,79 \\
\hline 4.5 Reclamation of degraded areas & 29 & 12382533,60 & 9457850,81 \\
\hline $\begin{array}{c}\text { 4.6 Support for institutions dealing } \\
\text { with environmental protection }\end{array}$ & 25 & 69717682,38 & 46082624,51 \\
\hline $\begin{array}{c}\text { 4.7 Biodiversity conservation } \\
\text { and environmental education }\end{array}$ & 49 & 64131290,99 & 43789140,73 \\
\hline Total & 221 & 822753157,20 & 523208211,69 \\
\hline
\end{tabular}


ROP impact on the environment and environmental infrastructure in Lower Silesia voivodeship in 2007-2013

Effects in terms of waste management

I will analyze the waste management first as the generation of waste is a growing worldwide problem due to the growth of population, the increase in the production of consumer goods and the technological progress [Ekoportal 2015]. Table 3 presents basic information on waste management in the Lower Silesia voivodeship in 2007-2013.

Over 6.5 million tonnes of waste were collected in the voivodeship in 20072013. More than 6,1 million tons were mixed waste, and just less than 0.5 million tons were collected selectively [Local Data Bank 2015].

We should note as positive the fact that the proportion of waste collected selectively in relation to the total waste has been increasing. This share was higher by 6,2 percentage points in 2013 compared to 2007. A downward trend can be observed in the amount of waste generated and recovered during the year. Also the share of the waste recovered out of all the waste generated during the year decreased in about 5,6 percentage points. The number of the operational landfill sites, on which municipal waste is being treated, had been cut down by over $60 \%$ in 2009-2013. At the same time, the area of operational landfill sites, on which municipal waste was treated, had been reduced by more than $40 \%$. In the years 2008-2013 more than 2500 unauthorized dumps were eliminated [Local Data Bank 2015].

The improvement of the situation in the area of waste management was accomplished thanks to projects which were realised under action 4.1 ROP. The implementation of these projects made it possible to recover more than 34,3 thousand tons of waste per year [Lower Silesia Marshal's Office 2014] covering the separate collection of waste for more than 58 thousand people [Lower Silesia Marshal's Office 2015]._This will also contribute

Table 3. Basic information on waste management in the Lower Silesia voivodeship in 2007-2013

\begin{tabular}{|c|c|c|c|c|c|c|c|}
\hline Specification & 2007 & 2008 & 2009 & 2010 & 2011 & 2012 & 2013 \\
\hline Waste collected during the year (thous. t) & 975,7 & 928,5 & 990,1 & 994,4 & 914,9 & 902,4 & 853,7 \\
\hline $\begin{array}{l}\text { Mixed waste collected du- } \\
\text { ring the year (thous. } t \text { ) }\end{array}$ & 929,2 & 867,5 & 912,5 & 923,7 & 849,4 & 828,8 & 760,1 \\
\hline $\begin{array}{l}\text { Waste collected separately du- } \\
\text { ring the year (thous. } t \text { ) }\end{array}$ & 46,6 & 61 & 77,6 & 70,8 & 65,5 & 73,6 & 93,7 \\
\hline $\begin{array}{l}\text { Waste collected separately in re- } \\
\text { lation to the total waste (\%) }\end{array}$ & 4,8 & 6,6 & 7,8 & 7,1 & 7,2 & 8,2 & 11,0 \\
\hline $\begin{array}{l}\text { Waste generated during the year recovered } \\
\text { (with the exception of municipal) (thous. t) }\end{array}$ & $\begin{array}{c}25 \\
020,2\end{array}$ & $\begin{array}{c}23 \\
883,6\end{array}$ & $\begin{array}{c}22 \\
804,8\end{array}$ & $\begin{array}{c}23 \\
163,1\end{array}$ & $\begin{array}{c}24 \\
196,0\end{array}$ & $\begin{array}{c}23 \\
581,8 \\
\end{array}$ & $\begin{array}{c}23 \\
268,5\end{array}$ \\
\hline $\begin{array}{l}\text { Share of waste recovered in waste } \\
\text { generated during the year }(\%)\end{array}$ & 72,9 & 70,8 & 68,5 & 69,0 & 69,0 & 68,3 & 67,3 \\
\hline $\begin{array}{l}\text { Operational landfill sites on which } \\
\text { municipal waste are treated (pcs) }\end{array}$ & . & . & 79 & 51 & 42 & 39 & 30 \\
\hline $\begin{array}{c}\text { Area of operational landfill sites on } \\
\text { which municipal waste are treated(ha) }\end{array}$ & . & . & 290,0 & 234,7 & 209,0 & 200,6 & 168,7 \\
\hline Number of unauthorized dumps (pcs) & . & 390 & 350 & 456 & 414 & 382 & 513 \\
\hline
\end{tabular}

Source: Own elaboration based on Local Data Bank 2015, https://bdl.stat.gov.pl/BDL/dane/temat\#. 
to the increase in the amount of waste collected selectively, and thus in the increase of the share of waste collected selectively over the total waste. More than 204 thousand people have been covered by the waste management system, which makes it possible to collect waste in a selective way [Lower Silesia Marshal's Office 2014]. The purchase of 162 containers and a vehicle for selective waste collection was another improvement made in this area. Seventy-four out of the 2505 unauthorized dumps were cleaned out thanks to these projects [Lower Silesia Marshal's Office 2014]. The implementation of the projects made possible the construction of $6 \mathrm{com}$ posting plants and 5 sorting plants as well as the modernisation of 4 existing sorting plants. Also, 5 waste transfer stations were built and the capacity of the landfills increased in about 460 thousand $\mathrm{m}^{3}$ [Lower Silesia Marshal's Office 2014].

Effects in terms of sewage and water infrastructure

Another very important area of conducted research is water and sewage infrastructures. Water is one of the renewable raw materials which carries a number of very important functions in the economy. The importance of these functions implies that water must be protected from contamination and should be used rationally and economically. Protection of both qualitative and quantitative water resources is an integral part of environmental protection [Chief Inspectorate of Environmental Protection 2014]. Basic information on water and wastewater management in the Lower Silesia in 2007-2013 is presented in table 4.

Table 4. Basic information about water and wastewater management in the Lower Silesia voivodeship in 2007-2013

\begin{tabular}{|c|c|c|c|c|c|c|c|}
\hline Specification & 2007 & 2008 & 2009 & 2010 & 2011 & 2012 & 2013 \\
\hline $\begin{array}{l}\text { The length of the water } \\
\text { supply network }(\mathrm{km})\end{array}$ & $\begin{array}{c}13 \\
604,6\end{array}$ & $\begin{array}{c}13 \\
888,3\end{array}$ & $\begin{array}{c}14 \\
110,8\end{array}$ & $\begin{array}{c}14 \\
429,5\end{array}$ & $\begin{array}{c}14 \\
345,2\end{array}$ & $\begin{array}{c}14 \\
681,4\end{array}$ & $\begin{array}{c}15 \\
127,1\end{array}$ \\
\hline $\begin{array}{l}\text { Population using the water- } \\
\text { line system (people) }\end{array}$ & $\begin{array}{c}2622 \\
028\end{array}$ & $\begin{array}{c}2625 \\
512\end{array}$ & $\begin{array}{c}2629 \\
053\end{array}$ & $\begin{array}{c}2668 \\
184\end{array}$ & $\begin{array}{c}2672 \\
697\end{array}$ & $\begin{array}{c}2679 \\
347\end{array}$ & $\begin{array}{c}2679 \\
644\end{array}$ \\
\hline $\begin{array}{l}\text { Share of population connected to } \\
\text { the water supply network (\%) }\end{array}$ & 91,1 & 91,3 & 91,4 & 91,5 & 91,6 & 91,9 & 92,1 \\
\hline $\begin{array}{c}\text { Length of working sewerage } \\
\text { network }(\mathrm{km})\end{array}$ & $\begin{array}{c}7 \\
201,3\end{array}$ & $\begin{array}{c}7 \\
584,0\end{array}$ & $\begin{array}{c}7 \\
918,9\end{array}$ & $\begin{array}{c}8 \\
248,6\end{array}$ & $\begin{array}{c}8 \\
733,2\end{array}$ & $\begin{array}{c}9 \\
290,4\end{array}$ & 9647,4 \\
\hline $\begin{array}{l}\text { Population connected to the } \\
\text { sewerage network (people) }\end{array}$ & $\begin{array}{c}1924 \\
740\end{array}$ & $\begin{array}{c}1940 \\
651\end{array}$ & $\begin{array}{c}1950 \\
600\end{array}$ & $\begin{array}{c}1986 \\
325\end{array}$ & $\begin{array}{c}2021 \\
539\end{array}$ & $\begin{array}{c}2044 \\
359\end{array}$ & $\begin{array}{c}2058 \\
871\end{array}$ \\
\hline $\begin{array}{l}\text { Share of population connected } \\
\text { to the sewerage network (\%) }\end{array}$ & 66,9 & 67,5 & 67,8 & 68,1 & 69,3 & 70,1 & 70,8 \\
\hline $\begin{array}{l}\text { The number of municipal wastewater } \\
\text { treatment plants (pieces) }\end{array}$ & 201 & 203 & 209 & 208 & 217 & 224 & 230 \\
\hline $\begin{array}{c}\text { Population using municipal } \\
\text { wastewater treatment plants (people) }\end{array}$ & $\begin{array}{c}2168 \\
458\end{array}$ & $\begin{array}{c}2185 \\
429\end{array}$ & $\begin{array}{l}2181 \\
935\end{array}$ & $\begin{array}{c}2215 \\
199\end{array}$ & $\begin{array}{c}2240 \\
268\end{array}$ & $\begin{array}{c}2250 \\
679\end{array}$ & $\begin{array}{c}2263 \\
230\end{array}$ \\
\hline $\begin{array}{c}\text { Share of population connected } \\
\text { to the municipal wastewater } \\
\text { treatment plants }(\%)\end{array}$ & 75,3 & 76,0 & 75,9 & 75,9 & 76,8 & 77,2 & 77,7 \\
\hline $\begin{array}{l}\text { Size (capacity) of wastewater } \\
\text { treatment plants by project }\left(\mathrm{m}^{3} / 24 \mathrm{~h}\right)\end{array}$ & $\begin{array}{l}772 \\
150\end{array}$ & $\begin{array}{l}798 \\
667\end{array}$ & $\begin{array}{l}789 \\
839\end{array}$ & $\begin{array}{l}794 \\
474\end{array}$ & $\begin{array}{l}869 \\
105\end{array}$ & $\begin{array}{l}840 \\
621\end{array}$ & $\begin{array}{l}840 \\
956\end{array}$ \\
\hline $\begin{array}{l}\text { Discharged treated wastewa- } \\
\text { ter during the year }\left(\text { dam }^{3}\right)\end{array}$ & $\begin{array}{c}100 \\
685,7\end{array}$ & $\begin{array}{c}97 \\
911,6\end{array}$ & $\begin{array}{c}99 \\
450,2\end{array}$ & $\begin{array}{c}102 \\
064,3\end{array}$ & $\begin{array}{c}102 \\
219,4\end{array}$ & $\begin{array}{c}101 \\
331,1\end{array}$ & $\begin{array}{c}102 \\
796,8\end{array}$ \\
\hline
\end{tabular}

Source: Own elaboration based on Local Data Bank 2014, https://bdl.stat.gov.pl/BDL/dane/temat\#. 
The length of the water supply network has increased systematically from year to year. This increase was of more than $1522,5 \mathrm{~km}$, which is more than $11,1 \%$. The number of people using the water-line system also have increased. Share of population connected to the water supply network increased by 1 percentage point. The length of working sewerage network also has been increasing from year to year. Its length has increased by $2446,1 \mathrm{~km}$. The population connected to the sewerage network increased systematically, rising by 3,9 percentage points in the years 2007-2013. The number of municipal wastewater treatment plants increased in 29. The population using municipal wastewater treatment plants reached about 95 thousand_increasing in about 2,4 percentage points. The size (capacity) of wastewater treatment plants grew almost 9\%. The amount of discharged treated wastewater in 2013 was higher by 102,8 dam $^{3}$ in comparizon to 2007. Analysis of these data allows us to draw a clear conclusion about the vast improvement of the situation in the area of water and wastewater management in the voivodeship [Local Data Bank 2015].

The projects implemented under RPO had a very significant impact on the situation in the area of water and wastewater in the voivodeship. $218 \mathrm{~km}$ of water supply network were built, which amounts to $14 \%$ of the network built between 2007 and 2013. 13682 people were connected to the water supply network. There was nearly $24 \%$ increase in the number of people using the water supply network. $282 \mathrm{~km}$ of sewerage network was built. It can therefore indicate that one in ten kilometers built in the voivodeship was built by the beneficiaries of the ROP. 17037 people were connected to the newly built or upgraded sewage system. The number of people using the sewerage network in 2007-2013 increased by
134131 people, so nearly $13 \%$ were connected through the implementation of the analyzed projects. The projects will help to discharge 2254490 $\mathrm{m}^{3}$ of sewage. 6 municipal wastewater treatment plants were built. $10 \mathrm{mu}-$ nicipal wastewater treatment plants were renovated. 8 water treatment plant were built and 9 were renovated. More than 2,5 thousand $\mathrm{m}^{3}$ of wastewater have possibly been treated. The information contained in the studies conducted so far shows the representatives of environment related institutions believe that a significant progress in the area of water and wastewater have been made. In the opinion of the representative Regional Fund for Environmental Protection and Water Management Wroclaw water and sewage is one of the areas where the greatest improvement is noticeable. There are municipalities in the voivodeship where the indicator of the share of the population using the sewerage system is close to $100 \%$. Representatives of environmental inspection indicated that the amount of waste water treatment plants in these communities, as well as their capacity is sufficient and there is no need for a further measures in this area. On the other hand, it is necessary to build sewerage network in rural areas. Financial support should be directed where there are gaps in the infrastructure in terms of both the construction of the sewerage system and the modernization of the sewerage treatment plants. In rural areas, we should consider the benefits of building domestic sewerage treatment plants. Representatives of environmental inspection also highlighted the improvement of the technical condition of the water supply network, which contributed to the reduction of water losses.

\section{Effects in terms of air quality}

Another area subjected to analysis was air quality. The primary objective 
of activities related to the protection of the air should be to maintain air quality in areas where it is good and to improve it in other areas [Voivodship Inspectorate of Environmental Protection 2012]. Such activities are very important due to the fact that air pollution have very significant impact on human health and on nature. Public statistic office provides very limited information on emissions because this information is limited only to the emissions from the so-called plants especially noxious to air purity. In 2013 in the voivodeship there were 146 of them. Information about emissions of air pollutants from plants especially detrimental to air purity are shown table 5 .

Emissions of gaseous pollutants were on average at the level of 16,1 million tonnes per year. Emission of particle pollutants was on average at the level of almost 5,0 million tons per year. Emissions of gaseous pollutants show downward trend. It is worth noting that almost all particle pollutants are retained or neutralised in pollutant reduction systems. The level of gas pollutants retained or neutralised in pollutant reduction systems was nearly $90 \%$ [Local Data Bank 2015].

The impact of industrial plants on air pollution is significant. However studies carried out for many years show that emissions from municipal and residential sectors, for example low emissions and road transport, have the greatest impact on the occurrence of exceedances of air quality standar$\mathrm{ds}$. The main reason is the combustion of low-quality fuel (eg. bad quality coal, not seasoned wood and coal silt), and also burning waste in furnace. This

Table 5. Emissions of air pollutants from plants especially noxious to air purity in 2007-2013

\begin{tabular}{|c|c|c|c|c|c|c|c|}
\hline Specification & 2007 & 2008 & 2009 & 2010 & 2011 & 2012 & 2013 \\
\hline $\begin{array}{l}\text { Emission of air pollutants- } \\
\text {-gases (thous. t/year) } \\
\text { including: }\end{array}$ & $\begin{array}{c}16 \\
677,1\end{array}$ & $\begin{array}{c}16 \\
958,6\end{array}$ & $\begin{array}{c}15 \\
466,6\end{array}$ & $\begin{array}{c}16 \\
343,7\end{array}$ & $\begin{array}{c}15 \\
942,2\end{array}$ & $\begin{array}{c}16 \\
039,6\end{array}$ & $\begin{array}{c}15 \\
286,4\end{array}$ \\
\hline carbon dioxide & $\begin{array}{c}16 \\
578,6\end{array}$ & $\begin{array}{c}16 \\
870,7\end{array}$ & $\begin{array}{c}15 \\
381,2\end{array}$ & $\begin{array}{c}16 \\
260,9\end{array}$ & $\begin{array}{c}15 \\
866,4 \\
\end{array}$ & $\begin{array}{c}15 \\
963,1 \\
\end{array}$ & $\begin{array}{c}15 \\
222,8 \\
\end{array}$ \\
\hline sulphur dioxide & 60,9 & 54,1 & 54,9 & 54,2 & 48,4 & 48,1 & 38 \\
\hline nitrogen oxides & 20,9 & 19,0 & 18,5 & 19,2 & 18,7 & 18,9 & 16,3 \\
\hline carbon oxides & 11,1 & 9,3 & 7,9 & 7,8 & 7,1 & 7,4 & 7,1 \\
\hline methane & 4,0 & 4,2 & 2,9 & 0,2 & 0,2 & 0,2 & 0,1 \\
\hline $\begin{array}{c}\text { Emission of air pollutants } \\
\text { - particulates ( } \mathrm{t} / \text { year) }\end{array}$ & 6,7 & 6,4 & 5,2 & 5,2 & 4,1 & 4,0 & 3,7 \\
\hline $\begin{array}{l}\text { Pollutants retained or neutralised } \\
\text { in pollutant reduction systems } \\
\text { - particulates(thous. } t / y e a r)\end{array}$ & 2408,9 & 2428,5 & 2204,3 & 2745,7 & 2812,4 & 2811,3 & 2554,8 \\
\hline $\begin{array}{l}\text { Pollutants retained or neutra- } \\
\text { lised in pollutant reduction sy- } \\
\text { stems - gases (thous. t/year) }\end{array}$ & 860,9 & 830,7 & 781,9 & 825,8 & 913,4 & 628,9 & 608,7 \\
\hline $\begin{array}{l}\text { Pollutants retained or neu- } \\
\text { tralised in pollutant reduction } \\
\text { systems in percent of pollut- } \\
\text { ants generated - particulates }\end{array}$ & 99,7 & 99,7 & 99,8 & 99,8 & 99,9 & 99,9 & 99,9 \\
\hline $\begin{array}{l}\text { Pollutants retained or neutralised in } \\
\text { pollutant reduction systems in per- } \\
\text { cent of pollutants generated - gases }\end{array}$ & 89,7 & 90,4 & 90,2 & 90,9 & 92,3 & 89,2 & 90,6 \\
\hline
\end{tabular}

Source: Own elaboration based on Local Data Bank 2014, https://bdl.stat.gov.pl/BDL/dane/temat\#. 
contributes to air pollution with PM10 and benz(A)pyrene. While car traffic is responsible for the emission of nitrogen dioxide and fine dust [Voivodship Inspectorate of Environmental Protection 2012].

The air quality observations in Lower Silesia Carried out in the last twenty years showed a significant improvement in air quality mainly in relation to sulfur dioxide, nitrogen dioxide and particles. Reduction of these emissions was mainly the result of the investment in industrial sector [Voivodship Inspectorate of Environmental Protection 2012]. Low emissions and emissions from transport remain to be problem. Air protection is one of the areas where there is still much to do. Support should be especially directed towards the elimination of low emissions.

The analyzed projects had small impact on the improvement of air quality because only 8 heat sources were modernized. Yearly emissions were reduced by $6,98 \mathrm{t}$ of sulfur dioxide, $0,58 t$ of nitrogen oxides and $742,3 t$ of carbon dioxide. These projects, however, helped to improve air quality by reducing emissions and concentration of pollutants in areas where they were implemented.

The research carried out so far [Lower Silesia Marshal's Office 2014] have shown poor air quality in the voivodeship. The exceedances of the acceptable level of concentration of pollutants tend to occurs during the winter. The main problem is the low emissions and the burning of waste in household stoves. Actions which will be taken in the near future should concentrate on encouraging the population to join the collective heating network. One of the factors which limits pollution in the cities is the construction of bypasses. This contributes to reducing the problem of environmental pollution caused by emissions from transport means. Therefore, the biggest challenge in the coming years will be the elimination of low emissions.

Effects in terms of flood infrastructure

Because of the risk of flooding in the region an important area that needs to be analyzed is the implementation of projects aimed at the construction and modernization of infrastructure which reduces flood risk. Despite the importance of flood protection issues the available data on the state of the infrastructure is very limited. It could be only indicated that there are $1326,5 \mathrm{~km}$ of embankments and 3005 different types of hydraulic structures in the voivodeship (storage reservoirs, tanks dry, relief channels, pumping stations, etc.) [Lower Silesia Board of Amelioration and Water Structures in Wroclaw].

The anti-flood infrastructure still requires a lot of attention which could indicate that the implementation of projects financed through the ROP contributed little to reduce the threat of flood and combating its effects.

More than 59 thousand residents are protected against flooding thanks to realized projects. 10 projects have been realized in the field of infrastructure related to flood prevention and drought. 16 flood protection facilities were constructed, renovated or rebuilt. 9135 hectares were covered by flood protection. More than $37 \mathrm{~km}$ of watercourses were modernized and more than $9 \mathrm{~km}$ of flood embankments were regulated. Over a 675 meters of retaining walls were built. 61,8 thousand. $\mathrm{m}^{3}$ of water were retained within the small and large retention structures [Lower Silesia Marshal's Office 2014].

\section{Effects in terms of reclamation}

The next analysed area was reclamation of devastated areas. In fact, thanks to the reclamation it is possible 
to restore the natural landscape, to improve the soil or to maintain the standards laid down by law in term of substances present in the soil. This helps to restore the natural value of degraded areas and to return them to utility [City Consulting Institute 2013]. Table 6 presents data on the area of land requiring reclamation and reclaimed and managed in Lower Silesia.

In this table we have some basic information about the situation in voivodship in years 2007-2013. At the end of 2013, there was more than 6,5 thousand hectares of devastated land in the voivodeship and more than 1,7 thousand hectares of degraded land requiring reclamation. In 2013 compared to 2007 there were about 217 hectares less of land demanding reclamation. In 2007-2013 it was possible to reclaim 732 hectares and to manage 189 hectares [Local Data Bank 2015].

The implementation of projects under the ROP, allowed to reclaim and recover 72,59 ha. Among the reclaimed land 45,31 hectares were former industrial areas and 1 ha was a post-military area. $2300 \mathrm{~m}^{2}$ of green spaces were transformed into recreational areas.

The surveyed projects are improving the environment by performing the remediation work. It should be noted, however, that in the voivodeship there are very substantial needs in the field of reclamation. The result is that the completed projects contributed little to reduce the area of land requiring reclamation.
Public statistics do not provide information on the actions taken to protect against the effects of natural and technological hazards, removing their effects, restoring the environment to appropriate state and strengthening selected elements of the environmental management system.

The analysis of the results of completed projects allows us to formulat a opinion of their significant impact on increasing protection against the effects of natural and technological hazards and removing their effects. They also helped to restore the environment to an appropriate state and to strengthen selected elements of the environmental management system. 4 projects were completed in the field of prevention of threats. 47 fire engines fitted with equipment to carry out rescue and disaster recovery were purchased. 18 units of firefighters were supported. More than $1139 \mathrm{~km}^{2}$ were covered by Measure Rescue Center for fire protection.

\section{Effects in terms of environmental education}

Another area subjected to analysis of the impact of ROP on the behavior of environmental potential of the region through environmental education and the creation of regional mechanisms for the protection and development of biodiversity, green spaces and special gardens. One of the factors determining the environmental potential

Table 6. The area of land requiring reclamation and reclaimed and managed in the voivodship in 2007-2013

\begin{tabular}{|c|c|c|c|c|c|c|c|}
\hline Specification & $\mathbf{2 0 0 7}$ & $\mathbf{2 0 0 8}$ & $\mathbf{2 0 0 9}$ & $\mathbf{2 0 1 0}$ & $\mathbf{2 0 1 1}$ & $\mathbf{2 0 1 2}$ & $\mathbf{2 0 1 3}$ \\
\hline $\begin{array}{c}\text { Devastated land requiring } \\
\text { land reclamation(ha) }\end{array}$ & 5289 & 5704 & $\mathbf{4 7 5 5}$ & $\mathbf{3 6 0 8}$ & 5892 & 5898 & 6569 \\
\hline $\begin{array}{c}\text { Degradaded land requiring } \\
\text { land reclamation(ha) }\end{array}$ & 1964 & 1719 & 2276 & 2441 & 2355 & 2178 & 1747 \\
\hline Land reclaimed during the year(ha) & 185 & 26 & 57 & 10 & 128 & 173 & 153 \\
\hline Land managed during the year (ha) & 2 & 120 & 7 & 10 & 0 & 9 & 41 \\
\hline
\end{tabular}

Source: Own elaboration based on Local Data Bank, https://bdl.stat.gov.pl/BDL/dane/temat\#. 
Table 7. Legal protected areas and the number of trees and bushes planted in years 2007-2013

\begin{tabular}{|c|c|c|c|c|c|c|c|}
\hline Specification & $\mathbf{2 0 0 7}$ & $\mathbf{2 0 0 8}$ & $\mathbf{2 0 0 9}$ & $\mathbf{2 0 1 0}$ & $\mathbf{2 0 1 1}$ & $\mathbf{2 0 1 2}$ & $\mathbf{2 0 1 3}$ \\
\hline Legal protected areas (ha) & $\begin{array}{c}360 \\
918,8\end{array}$ & $\begin{array}{c}359 \\
688,8\end{array}$ & $\begin{array}{c}362 \\
429,7\end{array}$ & $\begin{array}{c}369 \\
870,5\end{array}$ & $\begin{array}{c}371 \\
007,0\end{array}$ & $\begin{array}{c}371 \\
020,0\end{array}$ & $\begin{array}{c}371 \\
109,66\end{array}$ \\
\hline $\begin{array}{c}\text { Share of legally protected } \\
\text { areas in total area (\%) }\end{array}$ & 18,1 & 18,0 & 18,2 & 18,5 & 18,6 & 18,6 & 18,6 \\
\hline $\begin{array}{c}\text { The number of trees } \\
\text { planted (peaces) }\end{array}$ & 17204 & 12231 & 13301 & 13651 & 11921 & 8221 & 7072 \\
\hline $\begin{array}{c}\text { The number of bushes } \\
\text { planted (peaces) }\end{array}$ & 190499 & 133715 & 143332 & 120572 & 226679 & 70265 & 70839 \\
\hline
\end{tabular}

source: Own elaboration based on Local Data Bank, https://bdl.stat.gov.pl/BDL/dane/temat\#.

of the region is the area of protected areas. Basic information on this topic are presented in table 7.

The surface of protected areas has increased from $18,1 \%$ in 2007 to $18,6 \%$ of the total area at the end of 2013 . In the period between 2007 and 2013, the province planted over 83 thousand trees and more than 955 thousand bush [Local Data Bank 2015].

Analysis of the effects of co-financed projects does not allow us to formulate a clear conclusion to what extent these projects helped to preserve the environmental potential of the region through environmental education and the creation of regional mechanisms for the protection and development of biodiversity, green spaces and special gardens. Implementation of projects contributed without doubt to increase the level of environmental awareness and knowledge of the region's population. The effects are:

- 16 environmental education centers received support,

- 79 thousand people benefited from education centers

- 18,4 thousand people benefited from the established infrastructure for environmental education,

- close to 152 thousand people benefited from the paths of nature-education

- pedestrian and bicycle paths were marked with a length of $104 \mathrm{~km}$ on the Natura 2000 sites
- 9 nature paths were marked with information boards

- 920 hours of educational activities were conducted

- 15 viewpoints were built [Lower Silesia Marshal's Office 2014].

\section{Conclusions}

To sum up it's possible to say, that analysed projects contributed greatly to improve waste management in the voivodeship and to improve water and sewerage infrastructure. We can say that in Lower Silesia it is not necessary to build more water and sewerage infrastructure except for rural areas. In these areas, however, we should consider whether building sewage treatment plants is a better solution than supporting the construction of deep wells. On the other hand analysed projects had little impact on improving air quality in the voivodeship, improvement in flood protection infrastructure was not enough due to a very high demand in this area. In spite of the realized projects there is still a big demand to reclaim land. In the case of air quality, the main factor contributing to its pollution is low emissions caused by the burning of low-quality coal and burning waste in furnaces. A major issue is also the pollution caused by transport. Therefore, in the coming years support should be directed to projects that contribute to the 
improvement of air quality through the elimination of low emissions or reduction of the pollution caused by transport. Lower Silesia is an area at risk of flooding, which has occurred repeatedly in recent years. Therefore, despite the realization of many investments, it is necessary to continue to support flood prevention infrastructure. In the region there is also a large number of brownfield sites and old-military areas. That is the reason why significant resources should be spent

\section{Bibliography}

Bartniczak B., Ptak M. (2009), Finanse ochrony środowiska. Wybrane problemy, Wyd. Uniwersytetu Ekonomicznego we Wrocławiu, Wrocław 2009.

Beck, T. (2006). Evaluating humanitarian action using the OECD-DAC criteria: An ALNAP guide for humanitarian agencies. London, UK: Overseas Development Institute.

Chief Inspectorate of Environmental Protection (2014), Stan środowiska w Polsce, Raport 2014, Warszawa 2014.

City Consulting Institute (2013), Ekspertyza uwarunkowań prawnych procesu rewitalizacji i działań legislacyjnych, http://www.revitaklaster.pl/download/ekspertyza_uwarunkowan_prawnych_procesu_rewitalizacji_i_dzialan_ legislacyjnych.pdf, [ 25.03.2015].

Ekoportal (2015), Ochrona środowiska na co dzień, www.ekoportal.gov.pl, [11.02.2015].

Kenig-Witkowska M. M. (2011), Prawo środowiska Unii Europejskiej, Wyd. Wolters Kluwer business.

Local Data Bank (2015), www.stat.gov. $\mathrm{pl} / \mathrm{bdl}$, [07.02.2015]. on projects aimed at the reclamation of degraded land.

It should be notice of course that this improve were possible thanks to much more factors. Part of investments were done from other financial sources than ROP. Increasing environmental awareness is next factors which lead to improve in environment. Citizens started taking care about environment and also exert pressure on local and regional authority to do something for its protections.

Lower Silesia Board of Amelioration and Water Structures in Wroclaw (2014), Biuletyn Informacji Publicznej Dolnośląskiego Zarządu Melioracji i Urządzeń Wodnych. http://bip.dzmiuw.wroc.pl/mienie-podmiotu.html, [25.01.2014].

Lower Silesia Marshal's Office (2008), Regional Operational Programme for the Lower Silesian voivodship for 2007-2013, Wrocław 2008.

Lower Silesia Marshal's Office (2014), Raport Ewaluacja wpływu projektów realizowanych w Priorytecie 4 „Środowisko i bezpieczeństwo ekologiczne” i Priorytecie 5 „Energetyka” RPO WD oraz wyznaczenie pożądanych kierunków działań na przyszłość w obszarach objętych tymi priorytetami, Urząd Marszałkowski Województwa Dolnośląskiego, Wrocław 2014, http://rpo.dolnyslask.pl/index. php?id=1271\#c6663, [11.02.2015].

Lower Silesia Marshal's Office (2015), Sprawozdanie z realizacji Regionalnego Programu Operacyjnego dla Województwa Dolnośląskiego na lata 20072013, http://rpo.dolnyslask.pl/index. php?id=1778, [11.02.2015]. 
Mazur-Wierzbicka E. (2008), Wpływ integracji z Unią Europejską na finansowanie ochrony środowiska w Polsce, Studia i Prace Wydziału Nauk Ekonomicznych i Zarządzania nr 3/2008.

Ministry of Infrastructure and Development (2015), Linia demarkacyjna pomiędzy Programami Operacyjnymi Polityki Spójności, Wspólnej Polityki Rolnej i Wspólnej Polityki Rybackiej, https://www.mir.gov.pl/fundusze/ fundusze europejskie/linia demarkacyjna/strony/linia_demarkacyjna_ fe.aspx, [ 25.03.2015].
Ministry of Infrastructure and Development (2015), Umowy o dofinansowanie wg projektów, programów, poziomów wdrażania, województw, powiatów, gmin, danych dotyczących beneficjentów, tematu priorytetu i formy prawnej, czy projekt zakończony, http://www.funduszeeuropejskie.2007-2013.gov.pl/AnalizyRaportyPodsumowania/Strony/KSI_raporty. aspx, [11.02.2015 r].

Voivodship Inspectorate of Environmental Protection (2012), Raport o stanie środowiska w województwie dolnośląskim w 2012 r., Wrocław 2012.

\title{
Wpływ Regionalnego Programu Operacyjnego dla Województwa Dolnoślaskiego na lata 2007-2013 na środowisko i infrastrukturę ochrony środowiska w województwie
}

\begin{abstract}
Abstrakt
Stan środowiska a także infrastruktury ochrony środowiska jest jednym z czynników decydujących o jakości życia mieszkańców na danym terytorium. Celem głównym Regionalnego Programu Operacyjnego dla Województwa Dolnośląskiego na lata 2007-2013 było Podniesienie poziomu życia mieszkańców Dolnego Śląska oraz poprawa konkurencyjności regionu przy respektowaniu zasad zrównoważonego rozwoju. Realizacja tego celu miała zostać osiągnięta poprzez realizację celów przypisanych do poszczególnych priorytetów. Celem realizacji priorytetu IV Środowisko i bezpieczeństwo ekologiczne była poprawa stanu środowiska naturalnego, zapobieganie jego degradacji i zachowanie różnorodności biologicznej oraz walorów przyrodniczych Dolnego Śląska, a także poprawa poziomu bezpieczeństwa w regionie, poprzez przeciwdziałanie naturalnym i technologicznym zagrożeniom, likwidację ich skutków oraz wspieranie działających w tym zakresie służb ratowniczych. Celem opracowania będzie pokazanie jak realizacja projektów dofinansowanych w ramach priorytetu IV przyczyniła się do poprawy stanu środowiska oraz infrastruktury służącej ochronie środowiska. W tym celu porównane zostaną efekty zrealizowanych projektów z danymi statystycznymi dotyczącymi stanu środowiska i infrastruktury środowiskowej na terenie województwa. Analiza przeprowadzona zostanie w poszczególnych komponentach środowiska, które odpowiadają zakresowi tematycznemu poszczególnych działań realizowanych w ramach priorytetu IV. Analiza prowadzona będzie zatem w obszarze: gospodarki odpadami, gospodarki wodno-ściekowej, jakości powietrza, infrastruktury przeciwpowodziowej, rekultywacji terenów zdegradowanych, ochrony środowiska przed zagrożeniami naturalnymi i technologicznymi oraz ochrony bioróżnorodności.
\end{abstract}

Słowa kluczowe: Regionalny Program Operacyjny, środowisko, województwo dolnośląskie 
